(C) 2014

Дорогань-Писаренко Л. О., кандидат економічних наук

Полтавська державна аграрна академія

\title{
АНТИКРИЗОВИЙ МОНІТОРИНГ ФІНАНСОВОГО СТАНУ СІЛЬСЬКОГОСПОДАРСЬКИХ ПІДПРИЕМСТВ
}

\section{Рецензент - доктор економічних наук В. В. Писаренко}

Розглянуто існуючі підходи до оиінки показників фінансового стану сільськогосподарських підприємств. Визначено особливості здійснення антикризового моніторингу в сучасних умовах. Охарактеризовано існуючі стратегії антикризового моніторингу в умовах існуючого стану ефективності агропромислового виробництва. Наголошено на необхідності удосконалення методичних підходів до оиінки фінансового стану сільськогосподарських підприємств та необхідності здійснення заходів з оздоровлення суб'єктів господарювання, щчо мають ознаки кризового стану.

Ключові слова: криза, моніторинг, фінансовий стан, банкрутство, управління.

Постановка проблеми. Здійснення господарської діяльності суб'єктами господарювання аграрного комплексу, як і будь-якої іншої сфери національної економіки, пов'язане 3 мінливими умовами як внутрішнього, так і зовнішнього середовища та цілою низкою факторів ризику, що можуть спричинити виникнення та розвиток кризових явищ на підприємстві. Одним із найбільш ефективних способів пом'якшення впливу кризових чинників, що носять негативний характер, є використання відповідних науково-методологічних методів управління кризовими ситуаціями та оптимальне їх застосування i синтез. Однак для того, щоб не лише зменшити чи локалізувати вплив кризових явищ на підприємстві, а й мати можливість їх уникнути, неабияке значення має обгрунтування та використання таких методів антикризового управління, які варто застосовувати на превентивній та антиципативній стадіях розвитку кризових процесів, а саме метод моніторингу.

Аналіз останніх досліджень i публікацій, у яких започатковано розв'язання проблеми. Питання, пов'язані з оцінкою як самого фінансового стану, так і основних складових, що його визначають, досить широко висвітлені в працях науковців та вчених України, зокрема П. Т. Саблука, І. А. Бланка, В. А. Борисової, Н. А. Гринюка, Л. О. Лігоненка, Ю. А. Стельмащука, П. І. Гайдуцького, В. І. Мацибори та інших вчених [1-6]. Проте складність процесів пошуку шляхів розвитку аграрного сектора економіки та підвищення його ефективності на основі постійного антикризового моніторингу свідчать про необхідність подалыших досліджень цих проблем.

Мета дослідження. Відповідно до існуючих проблем, що існують у галузі сільськогосподарського виробництва, метою статті $\epsilon$ визначення ключових напрямів діагностики фінансового стану сільськогосподарських підприємств із метою недопущення виникнення кризових явищ та формування пропозицій щодо напрямів забезпечення ефективного антикризового моніторингу. Відповідно до існуючої мети були поставленні наступні завдання:

1) визначити особливості антикризового моніторингу;

2) охарактеризувати існуючий рівень ефективності агропромислового виробництва;

3) запропонувати стратегії оздоровлення сільськогосподарських підприємств.

Матеріали та методи дослідження. Для досягнення поставленої мети використані методи системного аналізу, загальної теорії статистики та основні положення загальної економічної теорії.

Результати дослідження. Основне завдання, що стоїть перед агропромисловим комплексом України, задоволення як населення продуктами харчування, так і промисловість сировинною базою. Закономірним наслідком зростання рівня ефективності виробництва є збільшення обсягів валової продукції як у натуральних одиницях виміру, так і у вартісних. У загальній системі антикризового управління сільськогосподарським підприємством одне з визначальних місць займає моніторинг, в межах якого відбувається збір та опрацювання первинної інформації, аналіз якої дає змогу діагностувати окремі організаційно-економічні «збої» у функціонуванні підприємства, а також дає можливість оперативно впливати на усунення окремих проявів кризових явищ у поточній діяльності підприємства та нівелювання їх наслідків. Будь-яке аграрне підприємство в процесі своєї діяльності здійснює виробництво різних видів сільськогосподарської продукції, відповідно до рівня ефективності виробництва якої й формується загальний фінансовий результат суб'єкта господарювання. 3 метою оцінки загального рівня розвитку кризових явищ в агропромисловому комплексі України проаналізуємо фінансові результати від реалізації та рівень рентабельності (збитковості) основних видів продукції в таблиці. 
ЕКОНОМІКА

Основні економічні результати діяльності сільськогосподарських підприємств у галузі сільського господарства у 2013 р.

\begin{tabular}{|c|c|c|c|c|}
\hline Види продукції & $\begin{array}{c}\text { Чистий дохід } \\
\text { від реалізації, } \\
\text { млн грн }\end{array}$ & $\begin{array}{c}\text { Фінансовий } \\
\text { результат від } \\
\text { реалізації, } \\
\text { млн грн }\end{array}$ & $\begin{array}{c}\text { Рівень } \\
\text { рентабель- } \\
\text { ності, \% }\end{array}$ & $\begin{array}{c}\text { Рівень рента- } \\
\text { бельності у } \\
2012 \text { р., \% }\end{array}$ \\
\hline $\begin{array}{c}\text { Продукція сільського господарства } \\
\text { і послуги }\end{array}$ & 121268,4 & 12497,8 & 11,5 & 20,2 \\
\hline Рослинництво і тваринництво & 116985,4 & 11905,4 & 11,3 & 20,5 \\
\hline Рослинництво & 89101,7 & 9060,9 & 11,3 & 22,3 \\
\hline Зернові та зернобобові культури & 46126,2 & 785,5 & 1,7 & 15,2 \\
\hline Насіння соняшнику & 20621,1 & 4634,1 & 29,0 & 45,8 \\
\hline Ріпак & 6172,0 & 480,7 & 8,4 & 21,4 \\
\hline Цукрові буряки (фабричні) & 1216,1 & 32,1 & 2,7 & 15,7 \\
\hline Картопля & 793,5 & 144,0 & 22,2 & $-21,5$ \\
\hline Овочі відкритого грунту & 635,4 & 52,0 & 8,9 & $-6,8$ \\
\hline Інша продукція рослинництва & 13537,4 & 2932,5 & 27,6 & 12,0 \\
\hline Тваринництво & 27883,7 & 2844,5 & 11,4 & 14,3 \\
\hline Велика рогата худоба на м'ясо & 1986,4 & $-1512,6$ & $-43,2$ & $-29,5$ \\
\hline Свині на м'ясо & 6353,7 & 11,8 & 0,2 & 2,0 \\
\hline Вівці і кози на м'ясо & 36,7 & $-18,8$ & $-33,9$ & $-40,0$ \\
\hline Птиця на м'ясо & 1141,0 & $-125,1$ & $-9,9$ & $-7,2$ \\
\hline Молоко & 7860,5 & 930,2 & 13,4 & 2,3 \\
\hline Яйця курячі & 7308,9 & 2357,2 & 47,6 & 52,6 \\
\hline Вовна & 2,1 & $-5,7$ & $-73,0$ & $-61,0$ \\
\hline Інша продукція тваринництва & 3194,4 & 1207,5 & 60,8 & 80,0 \\
\hline
\end{tabular}

Джерело: дані Державного комітету статистики України

У 2013 р. сільськогосподарськими підприємствами, як і в 2012 р., був отриманий позитивний результат від діяльності як у рослинництві, так і в тваринництві. У рослинництві підприємствами отримано 9060,9 млн грн прибутку, а рентабельність склала 11,3\% (у 2012 р., відповідно, 17029,8 млн грн і 22,3 \%). У 2013 р. було зафіксовано зниження рівня рентабельності виробництва більшості продукції рослинництва. Зокрема, прибутковість зернових і зернобобових культур скоротилася з 15,2 \% у 2012 р. до $1,7 \%$ у 2013 р., соняшника - $345,8 \%$ до $29,0 \%$, ріпаку - $321,4 \%$ до 8,4 \%, цукрових буряків (фабричних) - $315,7 \%$ до 2,7\%. Поряд із цим, за підсумками 2013 р., суттєво зросла рентабельність виробництва картоплі - 3 мінус 21,5 \% у 2012 р. до $22,2 \%$ у 2013 році. Спостерігається також зростання рентабельності виробництва овочів відкритого грунту, прибутковість якого становила $8,9 \%$ проти збитковості 6,8 \% у 2012 році. У галузі тваринництва, як і в 2012 р., було рентабельним вирощування свиней на м'ясо та виробництво молока і яєць. Порівняно з 2012 р. прибутковість молока збільшилася 3 $2,3 \%$ до 13,4 \%, але зменшилася прибутковість виробництва яєць із 52,6 \% до 47,6 \% та вирощування свиней на м'ясо - $32,0 \%$ до 0,2 \%. У 2013 р. вирощування сільськогосподарських тварин на м'ясо залишилося неефективним. Так, ще більш збитковим стало виробництво м'яса великої рогатої худоби, збитковість якого становила $43,2 \%$ проти 29,5\% у 2012 р., птиці - 9,9 \% проти 7,2 \%, вовни $73,0 \%$ проти 61,0\%. Однак зменшилася збитковість вирощування на м'ясо овець і кіз, яка становила 33,9\% проти 40,0\% у 2012 році. У цілому від діяльності в галузі тваринництва підприємствами отримано 2844,5 млн грн прибутку, а загальний рівень рентабельності становив 11,4 \% (у 2012 р., відповідно, 3169,6 млн грн і 14,3 \%). Отже, проведені розрахунки свідчать про неоднозначність динаміки ефективності сільськогосподарського виробництва та подекуди негативні тенденції, що вказує на необхідність постійного моніторингу фінансового стану суб'єктів господарювання 3 метою недопущення виникнення та розвитку кризових явищ. Більшість науковців як основу загального моніторингу фінансового стану підприємства 3 метою виявлення проблемних місць у його діяльності, а також прогнозування можливого банкрутства, використовують систему фінансово-економічних показників, що дають 


\section{EKOHOMIKA}

змогу різнопланово оцінити економічне становище окремого суб'єкта господарювання. Такий підхід вимагає постійної діагностики стану підприємства та наявності висококваліфікованих аналітиків, які здатні об'єктивно оцінити іï результати. Крім того, у зв'язку зі значною різноплановістю досліджуваної системи показників, із високим рівнем достовірності можна зробити висновок лише про наявність «вузьких місць» по окремим напрямам оцінки фінансового стану. Сдиний висновок про ймовірність банкрутства аналізованого суб'єкта господарювання зробити майже неможливо, оскільки в реальних умовах господарювання в значній частині випадків немає однозначної тенденції всіх показників, що характеризують його фінансово-економічний стан.

Таким чином, система показників моніторингу фінансового стану є доцільною для використання лише за аналізу поточного економічного становища і може бути придатною для діагностики ймовірності банкрутства лише у випадку наявності висококваліфікованих працівників економічного відділу. В системі антикризового моніторингу потрібно діагностувати не лише показники фінансовоекономічної діяльності, а й оперативно виявляти окремі проблеми, що виникають в процесі виробничої діяльності підприємства, та здійснювати прогнозування їх потенційного впливу на майбутній розвиток підприємства [1]. Комплексні дослідження, які повинні проводитися в системі антикризово- го моніторингу, мають за мету виявлення певних вузьких місць у діяльності суб'єкта господарювання, а також розробку комплексних заходів щодо їх подолання. У загальному підходи до діагностики кризових явищ на підприємстві можна поділити на два види. Перший вид базується на розрахунку системи коефіцієнтів і передбачає проведення їх експертних оцінок. До методик, що були розроблені на основі даного методу, слід віднести методики таких науковців, як Л. Лігоненко, А. Чернявського, А. Грязнової, А. Синягіна, О. Кононенка, О. Маханька, В. Бівера, В. Василенка та «Методичні рекомендації щодо виявлення ознак неплатоспроможності підприємства та ознак дій з приховування банкрутства, фіктивного банкрутства чи доведення до банкрутства» (Міністерства економіки України) від 19 січня 2006 року. Другий підхід базується на розрахунку єдиного інтегрального показника, значення якого дає змогу оцінити загальний фінансовий стан підприємства та ймовірність його банкрутства. Крім вищенаведених підходів має місце використання окремих специфічних методик, що грунтуються або на певному поєднанні попередніх методів, або 3 використанням бального чи рейтингового оцінювання досліджуваних показників. Відповідно до наших досліджень, весь комплекс стратегічних напрямів реалізації антикризового управління можна представити у вигляді наступної схеми (див. рис.).

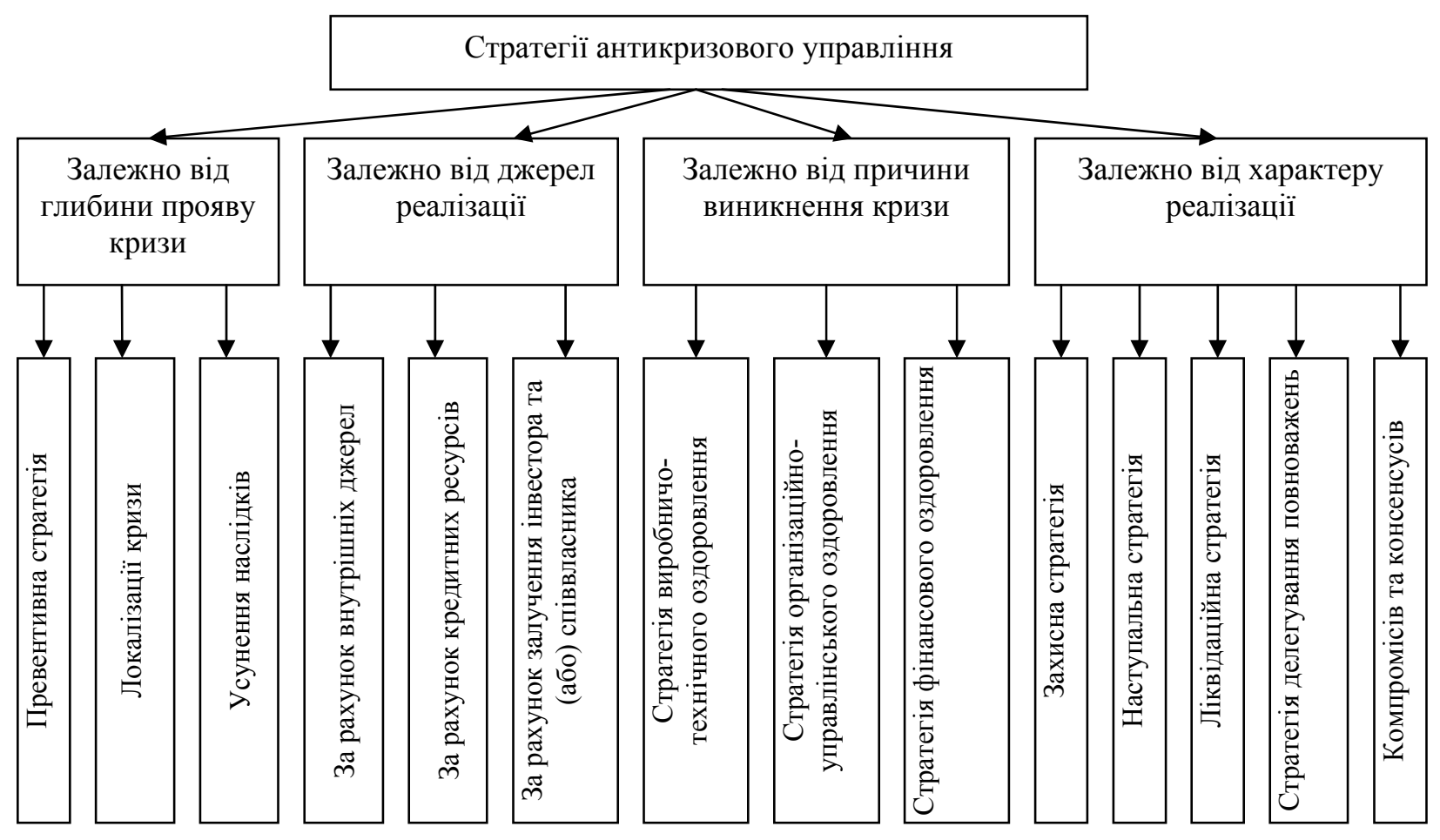

Рис. Класифікація стратегій антикризового управління підприємствами 


\section{EKOHOMIKA}

Вибір конкретного виду стратегії антикризового управління обумовлюється існуючим фінансово-економічним становищем суб'єкта господарювання, а також тією метою, яку планують досягти в процесі іï реалізації.

Висновки: 1. Оцінюючи все вищезазначене, слід зауважити, що існуючі методики дають можливість здійснити комплексну оцінку показників діяльності сільськогосподарських підприємств 3 урахуванням масштабів та напрямів їх діяльності. Проте сучасний стан розвитку економічного середовища загалом і галузі сільського господарства зокрема викликає необхідність удосконалення механізму антикризового управління 3 метою недопущення виникнення чи розвитку кризових явищ, що дасть змогу певним чином унеможливити банкрутство та ліквідацію окремих суб' єктів господарювання.

2. Існуюча наукова думка виокремлює цілу низку підходів до діагностики як окремих проявів кризових явищ, так і ймовірності банкрутства загалом. Для таких розрахунків використовуються як інтегральні методи оцінки, що дають змогу ідентифікувати фінансовий стан підпри-

\section{БІБЛІОГРАФІЯ}

1. Бланк И. А. Финансовый менеджмент : учеб. курс / И. А. Бланк. - К. : Ника-Центр, 1999. $528 \mathrm{c}$.

2. Борисова В. А. Методологічні основи аналізу фінансового стану підприємств агропромислового виробництва / В. А. Борисова // Фінанси України. - 2008. - №10. - С. 63-68.

3. Гринюк Н. А. Методичні підходи до обгрунтування індикаторів оцінки рівня фінансової безпеки підприємства / Н. А. Гринюк // Проблеми накуки. - 2008. - №6. - С. 35-40. ємства на основі результативного показника побудови багатофакторних моделей, так і методи, що передбачають розрахунок системи показників, експертний аналіз яких дає змогу зробити висновок про наявність або відсутність проявів кризових явищ, а також спрогнозувати динаміку фінансово-економічного становища господарської одиниці в майбутньому.

3. У системі антикризового управління важливе місце займає процес оздоровлення суб'єктів господарювання.

4. У загальному його вигляді в залежності від напрямів здійснення можна поділити на три види: виробничо-технічне (передбачає виконання комплексу дій $з$ метою підвищання рівня технічного забезпечення, а також покращання окремих технологічних операцій), оганізаційно-управлінське (характеризується заходами, спрямованих на підвищення якісного складу як апарату управління, так і окремих працівників) та фінансове (спрямоване на оптимізацію показників, що визначають рівень ліквідності, прибутковості, фінансової стійкості й ділової активності).

4. Лігоненко Л. О. Антикризове управління підприємством: теоретико-методологічні засади та практичний інструментарій / Л. О. Лігоненко. - К. : Київ. нац. торг.-екон. ун-т, 2001. -580 с.

5. Сокол О. Г. Методичні засади проведення моніторингу економічної стійкості сільськогосподарських підприємств / О. Г. Сокол // Економіка АПК. - 2009. - №3. - С. 45-48.

6. Стельмашук Ю. А. Методи діагностики фінансового стану і схильності підприємства до банкрутства / Ю. А. Стельмащук // Економіка АПК. - 2007. - №2. - С. 78-86. 